\title{
KEMAMPUAN MENULIS PUISI BERBASIS MEDIA LINGKUNGAN SISWA KELAS VII SMP NEGERI 5 KOTA BENGKULU
}

\author{
Meike Dwi Padhilah, Susetyo, dan Arono \\ Program Studi Pendidikan Bahasa Indonesia \\ Jurusan Pendidikan Bahasa dan Seni \\ FKIP Universitas Bengkulu \\ meikedwipadhilah96@gmail.com
}

\begin{abstract}
Abstrak
Tujuan penelitian ini untuk mendeskripsikan kemampuan menulis puisi berbasis media lingkungan siswa kelas VII SMP Negeri 5 Kota Bengkulu. Metode yang digunakan dalam penelitian ini adalah metode deskriptif. Data dalam penelitian ini berupa hasil tes kemampuan siswa menulis puisi menggunakan media lingkungan. Sumber data dalam penelitian ini adalah siswa kelas VII SMP Negeri 5 Kota Bengkulu. Teknik pengumpulan data dalam penelitian ini menggunakan tes kemampuan menulis puisi. Hasil penelitian ini menunjukkan bahwa kemampuan menulis puisi siswa kelas VII SMP Negeri 5 Kota Bengkulu berbasis media lingkungan secara umum berada pada nilai 72.23. Nilai rata-rata tersebut jika dikonversikan dengan perhitungan skala lima termasuk dalam kategori tinggi, karena hasil teks menulis puisi rata-rata siswa mendapatkan nilai 70-79.
\end{abstract}

\section{Kata Kunci: Kemampuan Menulis Puisi, Media Lingkungan}

\begin{abstract}
Learning to write poetry is faced with various obstacles. Obstacles that often occur in students are not optimal ability to write poetry. The purpose of this study was to describe the ability to write poetry based on environmental media for students of VII class SMP Negeri 5 Kota Bengkulu. The design of this study was a description methode. Through written test (writing poetry) is done by the way students are asked to write poems on student worksheets using enviromental media in accordance with the instructions on the student worksheet. The results of this study indicate that the ability to write poetry of students in class VII of VII class SMP Negeri 5 Kota Bengkulu based on environmental media is generally at a value of 72.73 . The average value if converted to a scale of five is in the high category, because the result of writing poetry average students get a score of 70-79.
\end{abstract}

\section{Keywords: the ability to write poetry, environmental media}

\section{PENDAHULUAN}

Menulis merupakan mengungkapkan ide atau gagasannya dalam bentuk karangan secara leluasa. Dalam hal ini, menulis membutuhkan skemata yang luas sehingga si penulis mampu menuangkan ide, gagasan, pendapatnya dengan mudah dan lancar. Skema itu sendiri adalah pengetahuan dan pengalaman yang dimiliki. Jadi, semakin luas skemata seseorang, 
makin mudah menulis. Menulis merupakan suatu keterampilan berbahasa yang dipergunakan untuk berkomunikasi secara tidak langsung, tidak secara tatap muka dengan orang lain. Menulis merupakan suatu kegiatan yang produktif dan ekspresif (Tarigan, 2013:3).

Moersey (dalam Tarigan, 2013:4) menulis dipergunakan oleh orang terpelajar untuk mencatat atau merekam, meyakinkan, melaporkan atau memberitahukan, dan memengaruhi, dan maksud serta tujuan seperti itu hanya dapat dicapai dengan tinggi oleh orang-orang yang dapat menyusun pikiran dan mengutarakannya dengan jelas, kejelasan ini bergantung pada pikiran, organisasi, pemakaian kata-kata, dan struktur kalimat. Dalam kehidupan moderen ini, tanpa mengabakaikan keterampilan berbahasa yang lain, terampil menulis sangat dibutuhkan. Keterampilan menulis perlu mendapatkan perhatian yang sungguh-sungguh. Sebagai salah satu kategori yang termasuk dalam aspek keterampilan berbahasa. Menulis memang bisa dilakukan oleh semua orang yang memiliki kecerdasan memadai. Berbeda dengan ketiga keterampilan berbahasa yang lain. Menulis harus dipelajari dan dilatih secara terus dan sungguh-sungguh.

Menulis merupakan sebuah proses kreatif menuangkan gagasan dalam bentuk bahasa tulis dalam tujuannya, misalnya memberitahu, meyakinkan, atau menghibur. Keterampilan menulis salah satunya diwujudkan dengan menulis sebuah karya puisi. menulis puisi merupakan kegiatan untuk melahirkan dan mengungkapkan perasaan, ide, gagasan dalam bentuk tertulis dengan memperhatikan diksi (pilihan kata), bentuk dan bunyi serta ditata secara cermat sehingga mengandung makna khusus sesuai dengan kondisi diri penulis dan lingkungan sosial yang ada di sekitarnya.

Media lingkungan merupakan media yang memberikan pengalaman langsung kepada siswa. Dengan media ling- kungan, siswa dapat berintaksi secara langsung dengan benda, lokasi atau peristiwa sesungguhnya secara ilmiah. Lingkungan sekitar kita dapat kita manfaatkan semaksimal mungkin dalam kegiatan pembelajaran yang kita lakukan. Lingkungan kita menyimpan berbagai jenis sumber dan media belajar yang hampir tak terbatas. Media-media yang terdapat di lingkungan sekitar, ada yang berupa benda-benda atau peristiwa yang langsung dapat kita pergunakan sebagai sumber belajar (Rahadi, 2004:49).

Suparno dan Yunus (2008:129) menyatakan menulis adalah kegiatan komunikasi berupa penyampaian pesan secara tertulis kepada pihak lain. Aktivitas menulis melibatkan unsur penulis sebagai penyampaian pesan, pesan atau isi tulisan, saluran atau media tulisan, dan pembaca sebagai penerima pesan.

Puisi merupakan bentuk karya sastra yang tersaji secara monolog. Menggunakan kata-kata yang indah dan kaya akan makna. Keindahan puisi ditentukan oleh diksi, majas, rima, dan iramanya. Kekayaan makna yang terkandung dalam puisi disebabkan oleh pemadatan segala unsur bahasa. Bahasa yang digunakan dalam puisi berbeda dengan bahasa sehari-hari. Puisi menggunakan bahasa yang ringkas, tetapi maknanya sangat kaya. Kata yang digunakannya adalah kata konotatif yang mengandung banyak penafsiran dan pengertian (Kosasih, 2008: 31).

Ahmad (dalam Pradopo, 2009:6) mengemukakan bahwa bila unsur-unsur dari pendapat-pendapat itu dapat dipadukan, maka akan didapat garis-garis besar tentang pengertian puisi yang sebenarnya.unsur-unsur tersebut berupa: emosi, imajinasi, pemikiran, ide, nada, irama, kesan pancaindra, susunan kata, kata-kata kiasan, kepadatan, dan perasaan yang bercampur-baur. Dapat disimpulkan ada tiga unsur yang pokok. Pertama, hal 
yang meliputi pemikiran, ide, emosi; kedua, bentuknya; dan yang ketiga ialah kesannya. Semua itu terungkap dengan media bahasa. Jadi, puisi itu mengekspresikan pemikiran yang membangkitkan perasaan, yang merangsang imajinasi panca indra dalam susunan yang berirama. Semua itu merupakan sesuatu yang penting, direkam, dan diekspresikan, dinyatakan dengan menarik dan memberi kesan. Puisi itu merupakan rekaman dan interpretasi pengalaman manusia yang penting, diubah dalam wujud yang paling berkesan.

Berdasarkan Kurikulum 2013, keterampilan menulis puisi terdapat pada materi kelas VII SMP. Selama ini pembelajaran menulis hanya memfokuskan pada penyampaian materi dan teori menulis. Kemudian siswa diminta menulis menurut imajinasi mereka masing-masing. Pembelajaran menulis puisi di SMP Negeri 5 Kota Bengkulu, khususnya di kelas VII dihadapkan pada berbagai kendala. Berdasarkan hasil pengamatan pada saat magang III, kendala yang sering terjadi pada siswa adalah kurang optimal kemampuan menulis puisi siswa. Hal ini disebabkan rendah tertariknya minat menulis puisi pada siswa. Kendala-kendala tersebut yaitu rendahnya kemampuan siswa terhadap pembelajaran menulis puisi, siswa kesulitan merangkai kalimat saat menulis puisi atau kesulitan mengembangkan ide menjadi puisi, siswa kesulitan menemukan ide atau imajinasi, dan rendah bervariasinya media. Kemampuan menulis siswa perlu ditingkatkan karena saat ini kemampuan menulis siswa belum optimal. Hal inilah yang menjadi alasan peneliti ingin meneliti kendala tersebut.

Kendala-kendala tersebut membutuhkan solusi. Solusi yang diharapkan adalah sesuatu yang dapat meningkatkan kemampuan siswa dalam menulis puisi, dapat menemukan inspirasi atau ide-ide yang luas sehingga dapat mempermudah siswa dalam menulis puisi. Media pembelajaran menjadi salah satu alternatif yang bisa dijadikan solusi. Sekarang ini banyak siswa yang mengenal dan menyukai seni. Di samping itu, seni juga membuat siswa makin bergairah dalam belajar, maka media pembelajaran dapat diwujudkan dengan kegemaran siswa akan seni tersebut. Pemilihan media pembelajaran yang digunakan tentunya harus sesuai dengan kebutuhan dan karakter siswa.

Berdasarkan pemaparan di atas, peneliti melakukan penelitian mengenai kemampuan menulis puisi menggunakan media lingkungan pada materi pembelajaran menulis puisi mata pelajaran Bahasa Indonesia untuk membantu kemampuan menulis puisi pada siswa.

\section{METODE}

Metode yang digunakan di dalam penelitian ini adalah metode deskriptif. Tempat penelitian dilakukan di kelas VII SMP Negeri 5 kota Bengkulu. Populasi dalam penelitian ini siswa kelas VII SMP 5 Kota Bengkulu tahun ajaran 2018/2019, sampel penelitian yang diambil yaitu sebanyak 28 siswa. Instrumen penelitian adalah alat yang dipakai untuk mengumpulkan data dalam penelitian. Teknik pengumpulan data yang digunakan dalam penelitian ini adalah tes. Adapun tes yang diberikan kepada siswa yakni berupa tes tertulis (menulis puisi) dilakukan dengan cara, siswa diminta untuk menulis puisi pada lembar kerja siswa dengan menggunakan media lingkungan sesuai dengan petunjuk yang ada pada lembar kerja siswa. Teknik analisis data dilakukan dengan langkah-langkah berikut: Memberikan penilaian pada puisi berbasis media lingkungan yang ditulis siswa. Penilaian puisi berbasis media lingkungan dilakukan oleh dua orang yaitu, peneliti sendiri dan guru yang mengajar Bahasa dan Sastra Indonesia. Menggabungkan skor dari P1 dan P2. Untuk mengetahui kemampuan menulis puisi berbasis media lingkungan siswa kelas 
VII SMP Negeri 5 Kota Bengkulu, penulis menggunakan rumus:

$\mathrm{M}=\frac{\sum X}{N}$, menentukan kemampuan menulis siswa dengan kategori interval tingkat penguasaan kemampuan menulis puisi.

\section{HASIL PENELITIAN DAN PEMBAHASAN Hasil penelitian}

Hasil Kemampuan menulis puisi terdapat beberapa aspek, aspek tersebut yaitu: gagasan atau ide, tema, isi, pemilihan kata, pemajasan, dan ejaan. Kemampuan menulis puisi siswa kelas VII SMP N 5 Kota Bengkulu berada pada nilai 72.23. Nilai rata-rata tersebut jika dikonversikan dengan perhitungan skala lima termasuk dalam kategori tinggi.

Hasil analisis data penelitian berdasarkan dari keseluruhan aspek digunakan teknik deskriptif, yaitu dengan rata-rata nilai dari semua sampel Perhitungannya sebagai berikut:

$$
\mathrm{M}=\frac{\sum X}{N}
$$

Keterangan:

$$
\begin{aligned}
& \mathrm{M}=\text { Nilai rata-rata } \\
& \sum X=\text { Jumlah skor sampel } \\
& \mathrm{N}=\text { Jumlah sampel }
\end{aligned}
$$

Tabel 1. Kemampuan Menulis Puisi secara keseluruhan

\begin{tabular}{|c|c|c|c|c|c|c|c|c|c|}
\hline \multirow{2}{*}{$\begin{array}{c}\text { R } \\
28\end{array}$} & \multicolumn{5}{|c|}{ Nilai Rata-Rata } & IA & $\%$ & $\begin{array}{c}\text { Kategori } \\
\text { Skala } \\
\text { Lima }\end{array}$ \\
\cline { 2 - 9 } & $\mathrm{Al}$ & $\mathrm{A} 2$ & $\mathrm{~A} 3$ & $\mathrm{~A} 4$ & $\mathrm{~A} 5$ & $\mathrm{~A} 6$ & & & \\
\hline Jumlah & 565.5 & 428.5 & 434.5 & 213.5 & 193.5 & 205.5 & $2,022.5$ & $2,022.5$ & \\
\hline $\begin{array}{c}\text { Rata- } \\
\text { Rata }\end{array}$ & 20.19 & 15.30 & 15.51 & 7.625 & 6.910 & 7.339 & 72.23 & 72.23 & Tinggi \\
\hline
\end{tabular}

Tabel di atas merupakan kemampuan menulis puisi secara keseluruhan dapat dilihat bahwa kemampuan siswa kelas VII SMP Negeri 5 Kota Bengkulu berada pada 72.23. Nilai rata-rata tersebut jika dikonversikan dengan perhitungan skala lima termasuk dalam kategori tinggi.

Keterangan:
A1 : Nilai Kemampuan Menulis Puisi pada Aspek Gagasan atau Ide

A2 : Nilai Kemampuan Menulis Puisi pada Aspek Isi

A3 : Nilai Kemampuan Menulis Puisi pada Aspek Tema

A4 : Nilai Kemampuan Menulis Puisi pada Aspek Pemilihan Kata

A5 : Nilai Kemampuan Menulis Puisi pada Aspek Pemajasan

A6 : Nilai Kemampuan Menulis Puisi pada Aspek Ejaan

$\sum$ A: Jumlah Seluruh Aspek Kemampuan Menulis Puisi

Rata-rata skor kemampuan menulis puisi berbasis media lingkungan siswa kelas VII SMP Negeri 5 Kota Bengkulu secara keseluruhan diperoleh 72.23 dari skor yang disajikan yaitu 100. Dengan demikian, jika disesuaikan dengan skor penilaian yang digunakan, maka nilai rata-rata kemampuan menulis puisi berbasis media lingkungan dalam perhitungan skala lima, nilai rata-rata dibagi skor maksimal dikali $100 \%$ adalah $72.23 \%$ dan termasuk pada kategori tinggi.

Berikut adalah diagram kemampuan menulis puisi secara keseluruhan.

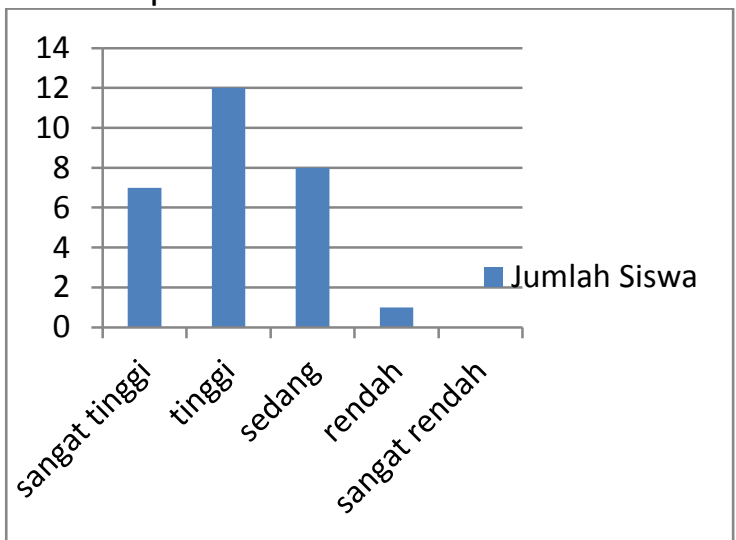

Dari diagram di atas terlihat bahwa kemampuan menulis puisi berbasis media lingkungan siswa untuk keterangan sangat tinggi berjumlah 7 siswa, keterangan tinggi berjumlah 12 siswa, keterangan keterangan sedang berjumlah 8 siswa dan keterangan rendah berjumlah 1 siswa. Berdasarkan hasil perhitungan frekuensi pada tabel dan 
diagram tersebut, dapat diketahui bahwa kemampuan menulis puisi berbasis media lingkungan siswa kelas VII SMP Negeri5 Kota Bengkulu terbagi atas 7 siswa termasuk kategori sangat tinggi, 12 siswa termasuk dalam kategori tinggi, 8 siswa termasuk kategori sedang, 1 siswa termasuk kategori rendah, tidak ada termasuk dalam kategori sangat rendah.

\section{Pembahasan}

kemampuan menulis puisi berbasis media lingkungan pada siswa kelas VII SMP Negeri 5 Kota Bengkulu dari keseluruhan aspek digunakan teknik deskriptif, yaitu menghitung rata-rata tingkat kemampuan. Rata-rata skor kemampuan menulis puisi berbasis media lingkungan siswa kelas VII SMP Negeri 5 Kota Bengkulu secara keseluruhan diperoleh 72.23 dari skor yang disajikan yaitu 100. Dengan demikian jika disesuaikan dengan skor penilaian yang digunakan, maka nilai rata-rata kemampuan menulis puisi berbasis media lingkungan dalam perhitungan skala lima, nilai rata-rata dibagi skor maksimal dikali $100 \%$ adalah $72.23 \%$ dan termasuk pada kategori tinggi.

Berdasarkan kemampuan secara keseluruhan aspek menulis puisi siswa kelas VII SMP Negeri 5 Kota Bengkulu. Data tiaptiap aspek akan disajikan sebagai berikut:

\section{Kemampuan Menulis pada Aspek Gagasan atau Ide}

tingkat kemampuan menulis puisi berbasis media lingkungan siswa kelas VII SMP Negeri 5 Kota Bengkulu pada aspek gagasan atau ide 2 siswa termasuk kategori sangat tinggi, 17 siswa termasuk kategori tinggi, 7 siswa termasuk kategori sedang, 2 siswa termasuk kategori rendah, dan tidak ada siswa dalam kategori sangat rendah. Kemampuan subjek penelitian pada aspek gagasan atau ide diperoleh nilai rata-rata sebesar 20.19. Nilai tersebut apabila dilihat dari penilaian aspek isi termasuk dalam kategori tinggi. Dengan demikian kemampuan menulis puisi berbasis media lingkungan siswa kelas VII SMP Negeri 5 Kota Bengkulu pada aspek gagasan atau ide termasuk kategori tinggi, karena siswa mampu menulis puisi yang didalamnya terdapat kesesuaian antara sebagian besar gagasan atau ide penciptaan sebuah puisi. Ide atau gagasan dalam menulis puisi merupakan ide-ide dari hasil pemikiran atau imajinasi. Hal tersebut menurut Situmorang (1981: 27), imaji adalah suatu pengalaman perasaan dan imagery adalah suatu gambaran pengalaman perasaan didalam kata-kata. Citraan (pencitraan) dalam puisi dimaksudkan untuk menimbulkan kesan atau suasana dari puisi. Pencitraan ini terfokus pada gambaran yang jelas, menimbulkan suasana khusus, membuat hidup gambaran dalam penginderaan, untuk menarik perhatian, untuk memberi kesan mental atau bayangan visual penyair menggunakan gambaran-gambaran angan. Citraan juga bermanfaat untuk menciptakan suasana kepuitisan. Bahkan ada penyair yang menyadarkan kekuatan puisinya pada citraan ini (Sukino, 2010: 120).

\section{Kemampuan Menulis pada Aspek Tema}

kemampuan menulis puisi siswa kelas VII SMP Negeri 5 Kota Bengkulu pada aspek isi 4 siswa termasuk kategori sangat tinggi, 21 siswa termasuk kategori tinggi, 3 siswa termasuk kategori sedang, tidak ada siswa dalam kategori rendah dan sangat rendah. Kemampuan subjek penelitian pada aspek tema diperoleh nilai rata-rata sebesar 15,30 . Nilai tersebut apabila dilihat dari penilaian aspek isi termasuk dalam kategori tinggi. Dengan demikian kemampuan menulis puisi berbasis media lingkungan siswa kelas VII SMP Negeri 5 Kota Bengkulu pada aspek tema termasuk kategori tinggi, karena Siswa mampu menulis puisi yang di dalamnya terdapat kesesuaian 
antara sebagian besar isi dengan tema lingkungan di dalamnya terdapat kesesuaian antara judul puisi dengan tema lingkungan. Tema suatu puisi merupakan kombinasi antara sintesa dari bermacammacam pengalaman, cita-cita, ide, dan bermacam-macam hal yang ada dalam pikiran penulis (Situmorang, 1981: 36).

\section{Kemampuan Menulis pada Aspek Isi} kemampuan menulis puisi siswa kelas VII SMP Negeri 5 Kota Bengkulu pada aspek isi 10 siswa termasuk kategori sangat tinggi, 14 siswa termauk kriteria tinggi, 2 siswa termasuk kategori sedang, 2 siswa termasuk kategori rendah, dan tidak ada siswa dalam kategori sangat rendah.Kemampuan subjek penelitian pada aspek isi diperoleh nilai rata-rata sebesar 15,51. Nilai tersebut apabila dilihat dari penilaian aspek isi termasuk dalam kategori tinggi. Dengan demikian kemampuan menulis puisi berbasis media lingkungan siswa kelas VII SMP Negeri 5 Kota Bengkulu pada aspek isi termasuk kategori tinggi, karena siswa mampu menulis puisi di dalamnya terdapat kesesuaian antara tema lingkungan dengan sebagian besar isi puisi dan pesan baik tersirat maupun tersurat dalam puisi Aspek isi adalah siswa mampu menulis puisi yang didalamnya terdapat kesesuaian antara tema lingkungan dengan keseluruhan isi puisi dan pesan yang tersirat maupun tersurat. Hal tersebut sesuai menurut Kosasih, (2008: 39), amanat yang hendak disampaikan oleh penyair dapat ditelaah saat kita memahami tema, rasa, dan nada puisi itu. Tujuan atau amanat merupakan hal yang mendorong penyair untuk menciptakan puisinya. Amanat tersirat dibalik kata-kata yang disusun, dan juga berada dibalik tema yang diungkapkan. Amanat yang ingin disampaikan oleh penyair secara sadar berada dalam pikiran penyair, namun lebih banyak penyair tidak sadar akan amanat yang diberikan.
4. Kemampuan Menulis pada Aspek Pemilihan Kata

kemampuan menulis puisi siswa kelas VII SMP Negeri 5 Kota Bengkulu pada aspek pemilihan kata 4 siswa termasuk kategori sangat tinggi, 16 siswa termasuk kategori tinggi, 8 siswa termasuk kategori sedang, tidak ada siswa dalam kategori rendah dan sangat rendah.Kemampuan subjek penelitian diperoleh pada aspek pemilihan kata nilai rata-rata sebesar 7.625. Nilai tersebut apabila dilihat dari penilaian aspek pemilihan kata termasuk dalam kategori tinggi. Dengan demikian kemampuan menulis puisi berbasis media lingkungan siswa kelas VII SMP Negeri 5 Kota Bengkulu pada aspek pemilihan kata termasuk kategori tinggi, karena siswa mampu menulis puisi yang hampir sebagian besarnya mengandung diksi (pilihan kata) yang sangat tepat yakni sesuai dengan konteks, mengandung bahasa konotasi (banyak makna), dan memiliki nilai estetis yang baik. Hal tersebut seperti menurut Tarigan (1993: 29), diksi atau diction berarti pilihan kata. Kalau dipandang sepintas lalu, maka kata-kata yang digunakan dalam puisi pada umumnya sama saja dengan kata-kata yang digunakan dalam kehidupan seharihari. Secara alamiah kata-kata yang dipergunakan dalam kehidupan sehari-hari mewakili makna yang sama; bahkan bunyi ucapan pun tidak ada perbedaan. Kata-kata yang dipergunakan dalam dunia persajakan tidak seluruhnya bergantung pada makna konotatif. Konotasi atau nilai kata inilah yang justru lebih banyak memberi efek bagi para penikmatnya.

\section{Kemampuan Menulis pada Aspek Pemajasan \\ kemampuan menulis puisi siswa} kelas VII SMP Negeri 5 Kota Bengkulu pada aspek pemajasan 11 siswa termasuk kategori sangat tinggi, 6 siswa termasuk kategori tinggi, 7 siswa termasuk kategori sedang, 4 siswa dalam kategori rendah, dan 
tidak ada termasuk siswa dalam kategpri sangat rendah. Kemampuan subjek penelitian diperoleh pada aspek pemajasan nilai rata-rata sebesar 6.910. Nilai tersebut apabila dilihat dari penilaian aspek pemajasan termasuk dalam kategori Tinggi. Dengan demikian kemampuan menulis puisi berbasis media lingkungan siswa kelas VII SMP Negeri 5 Kota Bengkulu pada aspek pemajasan termasuk kategori tinggi, karena siswa menulis puisi yang didalanya terdapat tiga variasi majas dengan memafaatkan majas perbandingan (metaforasimile), (penggantian (metonimi-sinekdok), pemanusian (personifikasi), berlebih-lebihan (hiperbola), dan sindiran (ironi). Menurut Kosasih (2008: 35), majas (figurative language) adalah bahasa yang digunakan oleh penyair untuk mengatakan sesuatu dengan cara membandingkannya dengan benda atau kata lain. Majas mengiaskan atau menyamakan sesuatu dengan hal lain. Maksudnya, agar gambaran benda yang dibandingkan itu lebih jelas.

\section{Kemampuan Menulis pada Aspek Ejaan} kemampuan menulis puisi siswa kelas VII SMP Negeri 5 Kota Bengkulu pada aspek ejaan 6 siswa termasuk kategori sangat tinggi, 12 siswa termasuk kategori tinggi, 10 siswa termasuk kategori sedang, tidak ada siswa dalam kategori rendah dan sangat rendah. Kemampuan subjek penelitian diperoleh pada aspek ejaan nilai rata-rata sebesar adalah 7.339. Nilai tersebut apabila dilihat dari penilaian aspek ejaan termasuk dalam kategori tinggi. Dengan demikian kemampuan menulis puisi berbasis media lingkungan siswa kelas VII SMP Negeri 5 Kota Bengkulu pada aspek ejaan termasuk kategori tinggi, karena siswa mampu menulis puisi yang sebagian besar ejaan didalamnya sudah sesuai dengan Ejaan Bahasa Indonesia.

\section{PENUTUP}

\section{Kesimpulan}

Kemampuan menulis puisi berbasis media lingkungan siswa kelas VII SMP Negeri 5 Kota Bengkulu berada pada nilai 72,23 . Nilai rata-rata tersebut jika dikonversikan dengan perhitungan skala lima termasuk dalam kategori tinggi.

\section{Saran}

1. Berdasarkan hasil penelitian, diharapkan agar penelitian ini dapat menjadi referensi para guru untuk mengukur kemampuan siswa dalam menulis puisi.

2. Penelitian ini juga diharapkan dapat menjadi refrensi untuk penelitian selanjutnya yang berhungan dengan kemampuan siswa menulis puisi berbasis media lingkungan.

\section{DAFTAR PUSTAKA}

Kosasih, E. 2008. Apresiasi Sastra Indonesia. Jakarta: Nobel Edumania.

Situmorang, B.P. 1981. Puisi Teori Apresiasi Bentuk dan Struktur. Medan: Nusa Indah.

Tarigan, Henry Guntur. 1993. Prinsip-prinsip Dasar Sastra. Bandung: Angkasa

Sukino. 2010. Menulis Itu Mudah Panduan Praktis Menjadi Penulis Handal. Yogyakarta: Pustaka Populer LKis.

Suparno dan Yonus Mohamad. 2008. Keterampilan Dasar Menulis. Jakarta: Universitas Terbuka.

Pradopo, Rachmat Djoko. 2009. Pengkajian Puisi. Yogyakarta: Gadjah Mada University Press.

Rahadi, Aristo. 2004. Media Pembelajaran. Jakarta: Direktur Jendral Pendidikan Dasar dan Menengah Direktur Tenaga Kependidikan. 